\title{
"Pesan los
}

\section{muertos de ayer}

y de mañana”. El

conflicto árabe-

israelí en el teatro

español actual

Paola Bellomi

Recebido em: 30 de outubro de 2016

Aceito em: 9 de novembro de 2016

(2012) Contacto: paola.bellomi@univr.it

en la Universidad de Verona $y$ es investigadora principal del proyecto nacional SIR E.S.THE.R. (Enquiry on Sephardic Theatrical Representation). Sus líneas de investigación van del teatro español contemporáneo a la sociología de la literatura.

Ha publicado varias monografías, capítulos de libros y artículos, entre los cuales se hallan las monografías Panico! La creazione secondo Fernando Arrabal, con prefacio de Fernando Arrabal (2013) y Periodismo cultural y compromiso politico. Las páginas literarias de Triunfo (2011). Con Silvia Monti, ha editado los volúmenes Fronteras, limites, conflines (2013) y Scene di vita. L'impesno civile nel teatro spagnolo contemporaneo 
Keywords: Contemporary

Spanish theatre; Israeli-

Palestinian conflict;

Representation of traumatic

events; Politics of memory

Palabras claves: Teatro español actual; Conflicto árabe-israelí; Representación de eventos traumáticos; Memoria histórica
Aim of this essay is to debate the relationship between the IsraeliPalestinian conflict and its representation in contemporary Spanish theatre. In order to do so, three working hypothesis will be formulated to examine the plays, that will be studied in connection with its historical context and the media environment; a special attention will be payed to the modes of the representation of traumatic events and its relationship with the politics of memory.

En este ensayo nos proponemos debatir la relación entre el conflicto árabe-israelí y su representación en el teatro español actual. Con este fin analizaremos un corpus dramático relacionado con el tema, basándonos en tres hipótesis de trabajo. La producción teatral así determinada se estudiará a partir de su entramado con el contexto histórico y con el contexto mediático en el que se ha producido; se prestará particular atención a los modos de representación de los eventos traumáticos y su relación con la recuperación de la memoria histórica.

Este artículo forma parte del proyecto de investigación nacional ESTHER - Enquiry on Sephardic Theatrical Representation (SIR 2014, RBSI14IDE8). 
"Pesan los muertos de ayer y de mañana". El conflicto árabe-israelí en el teatro español actual

En su diario, Max Aub anotaba: "Si tuviera que escoger entre unos y otros [israelíes y palestinos] - para luchar -, al decidirme por los judíos me daría la impresión de estar en nuestra guerra peleando a favor de Franco, guardadas todas las proporciones" (Aub, 1998, 374-375). Es 1966 y Aub se encuentra en Israel de profesor visitante en la Universidad Hebraica de Jerusalén; en el escaso año que el escritor permanece en el país, puede tocar con la mano la conflictiva realidad del joven Estado de Israel, que desembocaría unos pocos meses después en la Guerra de los seis días (5-10/06/1967). Y el juicio es muy amargo, como se deduce de la lectura de la colección de poemas Imposible Sinaí, redactados al término de este enfrentamiento relámpago; en una de las poesías, Aub atribuye al inventado poeta Arthur Goldberg los siguientes versos:

Aquí estaba la frontera eso dicen ¿por qué no he de creerlo?

Aquí pasaba, aquí estaba,

lo aseguran los mapas.

No hay nada, no había nada

trazado en tierra;

ya no habrá nunca.

¿Qué es una frontera?

¿Una bandera?

¡Bah! ¡Mía toda la tierra!

No toda, claro: ésta.

Y que los demás planten sus fronteras 
fuera de nuestra tierra (ter) (Cantado)

donde les dé la gana

fuera de nuestra tierra (Aub, 2002, 61-62).

Aub asiste a la radicalización del conflicto árabe-israelí y no renuncia a expresar su posición crítica frente a la mala gestión política de un enfrentamiento militar que mata a centenares de civiles para defender una frontera más imaginaria que real. La paradoja que el escritor apunta en su diario describe bien el vulnus de las reivindicaciones del Estado de Israel y las del Estado de Palestina (reconocido como entidad política independiente por las Naciones Unidas en 2012), o sea que el pueblo que había terminado por ser identificado como el chivo expiatorio de la barbarie nazi, se había transformado en cruel verdugo de otra minoría.

Max Aub es un comentador "privilegiado" del conflicto árabe-israelí: nacido en 1903 en una familia judía franco-alemana, recibe una educación laica; aunque el español no es su lengua materna, decide escribir su obra en ese idioma; partidario de la Segunda República, es internado en los campos de concentración de Vernet (Francia) y de Djelfa (Argelia); finalmente, en 1942 logra escapar y se exilia en México, país donde permanece hasta su muerte, en 1972.

La experiencia vital de Aub otorga, en cierto sentido, un mayor prestigio a su mirada crítica acerca de la cuestión palestina ${ }^{1}$. Aub fue uno de los po-

1. A propósito de la relación de Aub con sus orígenes judíos, se interroga Eleonor Londero, que afirma: "¿Puede suponer la condición de judío una diferencia sustancial en el modo de entender la función del intelectual? ¿Se reconocía Aub en una identidad semejante? [...] Sabemos que 
"Pesan los muertos de ayer y de mañana”. El conflicto árabe-israelí en el teatro español actual

cos autores de habla hispana que se acercó, con su obra dramática, al tema del antisemitismo nazi, cuando la barbarie todavía no había terminado y las persecuciones eran una herida viva; piezas como el monólogo De algún tiempo a esta parte (1939), la tragedia San Juan (1942) y el drama Comedia que no acaba (1947) representan unos de los primeros intentos de teatro en español que se mide con la experiencia traumática del exterminio de los judíos (Monti, 1992, 138-165; Vicente, 1991, 71-92). Como ha afirmado Silvia Monti: "Critico nei confronti dell' ebraismo ortodosso e intransigente, [Aub] condanna ripetutamente il sionismo estremista. Non si sente identificato perciò con gli ebrei perseguitati in quanto ebreo, ma in quanto uomo" (Monti, 1992, 138). La redacción de la antología poética Imposible Sinaí amplía, por tanto, la reflexión de Aub sobre el judaísmo, a raíz de sus experiencias de guerra y de persecución (la guerra civil española y la Segunda Guerra Mundial, el exilio, la búsqueda de una nueva identidad - que terminará en la elección de la nacionalidad mexicana); a través de las diferentes voces poéticas que pueblan la recopilación, el escritor hispano-mexicano ofrece, con su peculiar estilo, una original versión del enfrentamiento entre los dos bandos: en el mismo espacio geográfico, que a veces se denomina Israel y a veces Palestina, converge una multitud de experiencias humanas, cuyo común denominador es el trauma, causado en algunos casos por vio-

Aub pertenecía a esa élite de la burguesía europea que, por sus inquietudes culturales y su sincero cosmopolitismo, mal encajaba con los resentimientos nacionalistas o religiosos. Su caso es similar al de tantas otras víctimas de la locura que asoló al mundo y dividió lo que no debía haber sido dividido. Baste pensar en las experiencias de muchos otros intelectuales ilustres que fueron obligados por las circunstancias a exacerbar una identidad que nunca se habían planteado como necesaria" (Londero, 2002, 30-31). 
lencias pasadas (la diáspora sefardí), en otros, por la situación bélica entre israelíes y árabes.

Las palabras que Aub reserva, en su diario, a la experiencia en el "estado de los judíos", denotan el desengaño delante de los desastrosos resultados producidos por las mentirosas promesas de democracia y de justicia social hechas por los países hegemónicos. A propósito de Israel, en la entrada del 10 de noviembre de 1966 anotaba Aub en su diario: "Israel es otra cosa: un quiste puesto por Inglaterra para intentar quitarse de encima los muchos problemas que les planteaban los países árabes. Mejor dicho, lo fue. Ahora, es otra cosa: enredo del que nadie sabe cómo salir. Sólo el tiempo o la fuerza” (Aub, 1998, 373-374). Unas semanas después, el 1 de enero de 1967, el escritor vuelve sobre el tema:

La gran dificultad para determinar lo que es el Estado judío, que, por eso, no tiene todavía constitución, reside en la dificultad insuperable de no poder determinar lo que es un judío, a menos de recurrir a una definición religiosa. Efectivamente, es judío todo aquel que profesa la religión mosaica; pero, si esto se estampara como definición, la mayor parte de los israelitas no podrían ser considerados como ciudadanos (Aub, 2003, 309).

Max Aub es quizá el primer autor de lengua española en prestar tanta atención a este conflicto; y quizá sea también el primero en representar esos sucesos de forma dramática. La parte terminal de la entrada del diario, fechada el 31 de diciembre de 1966, presenta una estructura que mucho se parece a la de un canovaccio, y de hecho se titula El conflicto árabe-israelí 
"Pesan los muertos de ayer y de mañana". El conflicto Árabe-israelí en el teatro español actual

(Paso) (Aub, 2003, 307). Se trata de pocas líneas, en las que el dramaturgo describe de manera escueta a los personajes y la situación: nos encontramos en una tienda de ropa, en la ciudad vieja de Jerusalén. El dueño, que se llama Abd el Kader, deja que su hijo pequeño se suba encima de la mesa y le incita a que se lance entre sus brazos; cuando el niño lo hace, el padre se echa para atrás, dejándolo caer. Kader le dice que el gesto demostrativo sirve "para que no te fíes ni de tu padre" (Aub, 2003, 307). En ese momento pasa su mujer, afirmando que lo que acaba de decir el marido se remonta a un cuento judío, el marido niega y estalla una furiosa discusión sobre el origen árabe o judío de la frase de Kader. Paralelamente a esta escena, se desarrolla otra en la que el hijo mayor del comerciante discute con un guía turístico sobre los precios de las quincallas para los ingenuos compradores cristianos, musulmanes y judíos.

Con la ironía que caracteriza el estilo de Aub, el conflicto se reduce a sus términos mínimos, es decir: por un lado a la reivindicación de una supuesta primacía (cultural, histórica, religiosa, etc.) que en realidad es común a todas las partes interesadas; por otro lado, se subraya una tesis que Aub expresa también en otros puntos de su diario y en Imposible Sinaí, es decir que la naturaleza del conflicto es de raíz económica y no religiosa.

Aunque se trate de un texto esbozado, la dimensión política de la obra se transparenta tanto a nivel teatral (la representación del conflicto a través de la acción dramática) como a nivel textual, a través de la única de las dramatis personae que tiene nombre propio: Abd el Kader. Kader había sido el emir de Argelia que, en 1832, defendió la independencia de su país de la ocupación del ejército francés y, a pesar del fracaso de su ofensiva militar, Argelia 
le consideró héroe nacional. Es posible que a Aub le interesara esta figura histórica por su intento de unión del pueblo argelino con el marroquí en la lucha común contra la invasión francesa, un intento que fue obstaculizado por el sultán marroquí, que apoyó a los colonizadores; de ahí que el personaje del padre ponga a prueba a su hijo y le imparta esa lección. Pero, entrando ya en la especulación, otra explicación de la elección de este nombre podría estar relacionada con su significado: en árabe Abd el Kader significa "Servidor del Todopoderoso", o sea servidor de Allah. No obstante, se podría interpretar el significado del nombre como una referencia indirecta a los dos bloques políticos extranjeros que respaldaron el conflicto; estamos aludiendo al apoyo que las dos grandes potencias mundiales de la guerra fría, la URSS y los Estados Unidos, concedieron respectivamente a los palestinos y a los israelíes. El significado del nombre Abd el Kader, por tanto, podría ser una crítica, por parte de Aub, al compromiso aceptado por los dos ejércitos beligerantes para obtener la ayuda de Rusia y EEUU: los armamentos a cambio de la sumisión y de la servidumbre.

El brevísimo texto de Aub constituye una de las pocas muestras de un corpus muy reducido dedicado a la representación del conflicto israelí-palestino por parte de autores espańoles. Las hipótesis que explicarían este déficit son varias $\mathrm{y}$, de manera esquemática, podrían resumirse de la manera siguiente:

1. Un trauma todavía no asimilado que entrelaza la memoria de la expulsión de los judíos sefardíes, la posición franquista frente a la Shoah y las consecuencias del apoyo político espańol al Estado de Israel. 
"Pesan los muertos de ayer y de mañana". El conflicto Árabe-isRaelí en el teatro español actual

2. La dificultad de representar un conflicto extrańo, alejado del horizonte cultural español y cuyos límites son de difícil definición (¡es una guerra de religión? ¿Se trata de terrorismo político?).

3. La dificultad de medirse con unos acontecimientos traumáticos todavía actuales (se trata de un conflicto no terminado).

La primera hipótesis, por tanto, supone que el conflicto árabe-israelí esté enlazado con la historia de los judíos en España y que esta herencia vergonzosa haya tenido como consecuencia el olvido o la desatención por parte de los creadores. Esta posible explicación estaría respaldada por una mirada sobre la producción dramática sobre la Shoah en el ámbito ibérico.

De acuerdo con lo que propone Alejandro Baer en su sugerente estudio sobre la memoria del Holocausto en España (2011), podemos recordar que el franquismo quiso cerrar los ojos mientras era un aliado del nazismo por considerar el genocidio como un asunto "entre judíos y alemanes" (Baer, 2011, 504); pero nada más caer Hitler y Mussolini, Franco reivindicó la conexión con los hijos herederos de Sefarad, fundando el mito de una dictadura blanda, que se comprometió en la salvación de los judíos espańoles encerrados en los campos nazis. La operación de maquillaje servía para conquistar el apoyo internacional al término de la Segunda Guerra Mundial, pero, como han establecido los historiadores, la realidad fue muy distinta².

2. Como explica Baer, "el gobierno de Franco actuó de acuerdo a una razón de Estado que dictaba una implicación mínima en el salvamento de judíos en el periodo de máxima urgencia (entre 1942 y finales de 1944). Consignas de pasividad dadas a los diplomáticos, limitación de beneficiarios de la nacionalidad española y medidas dilatorias en lo concerniente a las repatriaciones 
Entre las muchas consecuencias de la ambigua posición franquista frente al Holocausto, se hallan la manipulación y el desconocimiento de los hechos históricos por una parte de los españoles, que crecieron estudiando en manuales que ignoraban por completo o casi la persecución nazi; $y$, lamentablemente, se trata de una ignorancia que la democracia no logra enmendar hasta los años noventa, cuando, con motivo del quinto centenario del edicto de expulsión de los sefardíes, se celebraron algunas iniciativas dirigidas a la recuperación de esta memoria histórica. El recuerdo de Sefarad se une al de las persecuciones nazis y los dos temas vuelven a ser de actualidad para la opinión pública española. Como afirma Baer, "a partir de 2000 se produce un progresivo y muy significativo cambio en lo que respecta al interés por la Guerra Civil y el franquismo en Espańa. El detonante es un heterogéneo movimiento cívico de enorme vitalidad organizado en torno a la llamada «recuperación de la memoria histórica»" $(2011,506)^{3}$. Esta vuelta a la

fueron los rasgos de esta política oficial. Los protegidos y salvados del exterminio deben su existencia a la iniciativa y determinación de los cónsules que a título individual intercedieron por ellos y, también, a la evolución de la guerra. En la medida que la balanza se inclinaba hacia la victoria aliada, fue más fácil convencer al gobierno de España para que accediera a la repatriación de los judíos con nacionalidad española - que no fue tal, sino más bien una operación de asilo y tránsito -, y también para que fuera flexible respecto al paso clandestino de refugiados por la frontera pirenaica" (2011, 504, nota 3).

3. Están todavía por evaluar las consecuencias concretas de la conocida y controvertida "Ley $12 / 2015$, de 24 de junio, en materia de concesión de la nacionalidad española a los sefardíes originarios de España” (BOE-A-2015-7045). A pesar de los tonos entusiásticos que el rey Felipe VI usó en la ceremonia de promulgación del texto (“Cuánto os hemos echado de menos!", Alberola, 30/11/2015), la concesión de la nacionalidad española a los "hijos de Sefarad" no ha dejado de suscitar polémicas, como la planteada por los propios sefardíes, que rechazan el papel de "hijo pródigo", frente al "padre misericordioso", o sea España. Una parte de los herederos de los expulsados niegan darle legitimidad a una operación que quiere olvidarse de las violencias y las persecuciones que originaron la diáspora de los sefardíes ibéricos. Además, la Ley 12/2015 crea 
“Pesan los muertos de ayer y de mañana”. El conflicto Árabe-israelí en el teatro español actual

Paola Bellomi

actualidad de un tema silenciado durante décadas se refleja también en el teatro, como demuestra por ejemplo la producción de comienzo del siglo XXI de Juan Mayorga, el dramaturgo que quizá más ha contribuido al rescate de la memoria de la Shoah en ámbito ibérico; su trilogía reservada a este argumento remonta a la década de los años 2000: Himmelweg, sobre el campo de contentración de Theresienstadt, es de 2002; JK, sigla por "Jude" y "Kommunist", es de 2005; y, finalmente, El cartógrafo, sobre el gueto de Varsovia, es de $2009^{4}$.

Volviendo a retomar la hipótesis sobre la relación entre el evento traumático de la Shoah y el teatro español, hemos intentado reconstruir sumariamente las etapas que han llevado de las posiciones negacionistas del franquismo a la recuperación de la memoria histórica, a través del teatro. Un cortocircuito se verifica cuando la política se apodera, de manera ideológica, de las manifestaciones reservadas al recuerdo de las víctimas de las persecuciones: se acercan los nazis a los terroristas etarras; después del descubrimiento de las mentiras del "impostor" Enric Marco, ya no se vuelve a invitar a los representantes republicanos en las celebraciones organizadas por las asociaciones judías; se acusa a la izquierda antisionista de antisemitismo, etc. (Baer, 2011, 507-514); en resumen, la memoria de la Shoah en España termina por ser un terreno minado, expuesto a cualquier tipo de especulación,

otra situación injusta, o sea la disparidad de tratamiento entre los descendientes de los hebreos y los de los moriscos, ellos también perseguidos y finalmente expulsados de España en 1609.

4. Para un análisis detallado de la "trilogía de la Shoah" de Juan Mayorga, se recomienda el estudio introductorio de Enrico Di Pastena que acompaña la edición italiana de los tres textos (Di Pastena, 2014, 5-62). 
entre las que se halla también la equivocada superposición entre la historia de los hebreos perseguidos por Hitler y la agresiva política del gobierno de Israel. De hecho, una de las preguntas más frecuentes acerca del conflicto árabe-israelí es: ¿cómo pueden los judíos, después de la experiencia nazi, ejercer tanta violencia sobre una minoría como la de los palestinos? Confundir identidad judía e identidad israelí tiene como consecuencia inmediata la vuelta a episodios antisemitas en todo el mundo.

El tratamiento reservado a las noticias sobre este enfrentamiento en los medios de comunicación espańoles y en los actos públicos recurre muy a menudo a locuciones como: "Holocausto palestino", "genocidio de Gaza" o "campos de concentración en Palestina" (Baer, 2011, 515); es decir que, de acuerdo con cuanto afirmado por Baer, "en torno al lugar común «Holocausto» y con el trasfondo del conflicto israelí-palestino se articulan en España discursos activadores de una nada desdeñable hostilidad antisemita” $(2011,516)$. Aunque sería incorrecto sostener que la totalidad de la información española es partidaria del bando palestino, hay que considerar aquel fenómeno que "homogeneíza el flujo informativo hacia los diarios y reduce la pluralidad interpretativa de la ciudadanía” (Maciá-Barber, 2013, 95). Es decir que la información reservada, en los periódicos ibéricos, a la cuestión palestina, muy a menudo acude a una simplificación de los términos de discusión.

Son interesantes los resultados de una encuesta de 2011 sobre la relación entre opinión pública espańola y el conflicto palestino-israelí. A la pregunta “¿Qué opinión tienen los españoles sobre los musulmanes?”, el porcentaje de respuestas "favorables" pasa del 48\% (en 2005) al 32\% (en 2008), el 
"Pesan los muertos de ayer y de mañana". El conflicto Árabe-isRaelí en el teatro español actual

de respuestas "desfavorables", en el mismo período considerado, aumenta del 38\% al 51\%. A la pregunta "¿Qué opinión tienen los españoles sobre los judíos?", el porcentaje de respuestas "favorables" disminuye del 59\% al $39 \%$ y las "desfavorables" asciende del 20\% al 48\% (Córdoba Hernández, 2011, 161-162). Sin embargo, en el imaginario colectivo español, la figura del palestino no se asimila a la del árabe-musulmán, con lo cual tampoco se relacionan los grupos armados como Hamas a la totalidad del pueblo palestino (Córdoba Hernández, 2011, 160). En cambio los españoles tienen más dificultad a la hora de diferenciar la figura del israelí de la del hebreo. Lo que sí resulta de la encuesta es que la desconfianza que en España se muestra frente a la política israelí no tiene un fundamento religioso, sino político; es decir, la opinión pública condena la estrategia agresiva de Israel por su violencia militar y no por sus reivindicaciones bíblicas (Israel considerada como la tierra prometida por Dios al pueblo judío) (Córdoba Hernández, 2011, 162). Comentando los resultados de su encuesta, Córdoba Hernández llega a unas conclusiones interesantes:

Aunque Oriente Próximo atraiga constantemente la atención mediática, en España no se ha construido una opinión madura al respecto. Esto se nota en la repetición sistemática de tópicos y clichés que los propios colectivos pro israelíes o pro palestinos impiden que se superen. [...] También los medios caen rápidamente en los tópicos comunes. En cualquier conflicto internacional la complejidad propicia las explicaciones simplistas, pero, en el palestino-israelí hay que añadir un componente adicional, la prolongación del enfrentamiento en el tiempo. [...] Resulta más sencillo refugiarse en una 
imagen o un lugar común que no exija más explicaciones y ayude a sacar conclusiones simples $(2011,169)$.

La interpretación de estos datos nos permite plantear la segunda hipótesis relacionada con la dificultad de representar, con el lenguaje teatral, un conflicto extraño, alejado del horizonte cultural español y cuyos límites son de difícil definición.

De hecho, según la posición ideológica de quien se exprese para referirse al enfrentamiento, se hablará de guerra de agresión (con los israelíes como parte activa) o de terrorismo palestino (con los ataques suicidas y homicidas en Jerusalén y en los territorios controlados por Israel). "En el conflicto palestino-israelí - afirma Igor Barrenetxea Marañón - la memoria de la Shoá es fundamental a la hora de encontrar la primera contradicción significativa en la manera de concebir para los judíos su Historia: ¿victimismo o heroísmo?" $(2013,3)$; pero esta misma pregunta resuena al referirse a la historia de los palestinos. La respuesta depende claramente del punto de vista elegido por el intérprete que somete su obra - sea ésta un drama teatral, un documental fílmico, un fotoreportaje, etc. - al receptor.

En esta "dialéctica de la violencia" (Barrenetxea Marañón, 2013, 2), la representación del conflicto depende del foco de la cámara; para dar tan solo un par de ejemplos: si nos fijamos en la filmografía reciente de Israel, dirigida a un público principalmente de ese entorno, películas como Zero Motivation (2014) de Talya Lavie presentan el día a día del conflicto desde la perspectiva israelí: en un cuartel del ejército situado en el medio del desierto, los soldados tienen que esperar la llegada del enemigo pero, como en la 
“Pesan los muertos de ayer y de mañana”. El conflicto Árabe-israelí en el teatro español actual

novela de Dino Buzzati El desierto de los Tártaros, el tiempo y la vida pasan inútilmente. En esta tragicomedia, la representación del conflicto queda al fondo, pero se da como una guerra de defensa (la presencia de un ejército regular, que patrulla las líneas "asechadas" por el enemigo). Por otro lado, si pasamos a la representación del mismo sujeto, pero desde la perspectiva palestina, los términos cambian radicalmente $y$, muy a menudo, se presenta el conflicto como una guerra de agresión inicua y desequilibrada; se subraya la superioridad de la fuerza militar de Israel y la agresividad de la política de colonización en los territorios palestinos frente a la penuria de medios a disposición de la resistencia palestina. Los ejemplos podrían ser muchos, pero solo recordamos la película del director vasco y periodista de guerra Unai Aranzadi titulado Neverthless, Al Quds (2015); se trata de un documental que mezcla el registro objetivo de la documentación de los hechos con el montaje del cine narrativo, con lo cual el resultado es un storytelling, entre realidad y ficción, de las agresiones israelíes en la ciudad vieja de Jerusalén (Al Quds, en árabe), la parte habitada por la población árabe-israelí. El documental pretende demostrar las razones de la resistencia pacífica de los palestinos frente a la violencia concreta y psicológica de Israel (la confisca y el derrumbe de las casas y la construcción del muro de separación entre las zonas árabes y las israelíes). Se evita mostrar los ataques suicidas o las agresiones improvisadas con cuchillos; la respuesta violenta de los palestinos se traduce, en imágenes, con la representación de una escena en la que unos niños atacan con piedras un coche israelí, que termina por atropellarlos.

Los ejemplos citados, con las múltiples diferencias que los separan, nos plantean el interrogante de cómo se representa el conflicto, nos hablan de 
la dificultad de interpretar un enfrentamiento extraño, ajeno. Con respecto al uso, en la prensa española, de las imágenes de niños vinculadas a las noticias sobre la cuestión palestina, Carlos Maciá-Barber se pregunta: “¿Es realmente necesario mostrar el horror y las consecuencias de la violencia en los rostros y cuerpos infantiles?" y contesta: "La ausencia de imágenes provoca la desaparición del conflicto" $(2013,90)$. Tanto en el cine como en los fotoreportajes sobre el tema que aquí nos ocupa, se emplea la potencia comunicativa de la imagen - muy a menudo se trata de primeros planos de los rostros de las víctimas de las violencias - para captar la mirada del espectador/lector, usando la fuerza empática que la visión de unas personas dolientes suscita.

Y en el teatro español actual, ¿cómo se ha representado el conflicto árabe-israelí? La respuesta es que la escena ha quedado prácticamente vacía.

De un rápido e incompleto bosquejo, la nómina comprende un número muy reducido de títulos: Reservado el derecho de admisión (1993) de Petra Martínez y Juan Margallo; El suicidio del ángel (2007) de Autora Mateos; So happy together (2008), de Jesús Laiz, Yolanda Pallín, José Ramón Fernández y Laila Ripoll. A estos textos, de autores propiamente españoles, se puede añadir Tierra del fuego (2013) del argentino Mario Diament, obra estrenada en el Teatro Central de Sevilla (11-12/03/2016) y luego llevada a la escena en el Espańol de Madrid (21/04-12/06/2016). También conviene nombrar la "trilogía del refugiado" del madrileńo Marco Magoa (pseudónimo de

5. En las páginas que siguen se quiere proporcionar una escueta descripción del argumento de cada obra que constituye el corpus relacionado con el conflicto árabe-israelí. Seguramente hace falta una indagación más profunda sobre los textos mismos y su puesta en escena. 
"Pesan los muertos de ayer y de mañana". El conflicto Árabe-israelí en el teatro español actual

Marco Márquez Muñoz de Luna), centrada en las tragedias humanas que están acaeciendo en el Mediterráneo; los títulos que componen la trilogía son: El cielo y yo (2015), Nada (2015) y Mare Nostrum. Finis Somnia Vestra (2016), estrenadas respectivamente en Amán (Jordania), El Cairo (Egipto) y Copenague (Dinamarca) ${ }^{6}$. Por último, cabría mencionar el laboratorio "Construyendo la paz desde el conflicto" (11-12/03/2016) realizado en la ciudad de Guernica por el centro cultural ASTRA con la participación del grupo israelí-palestino Combatants for Peace, constituido por ex-combatientes de ambas partes; a través de los recursos del teatro del oprimido, el laboratorio quería favorecer algunas herramientas de resistencia no-violenta, a partir de la experiencia de los miembros de Combatants for Peace, que trabajan en las zonas ocupadas por el ejército israelí7.

La tercera hipótesis intenta explicar la poca asiduidad con la que el teatro español se ha confrontado con este tema: la supuesta dificultad de medirse con unos acontecimientos traumáticos todavía actuales ha obstaculizado la creación de textos y puestas en escena que representaran el conflicto desde la perspectiva española. Pero la hipótesis es claramente falaz puesto que el teatro desde siempre se ha ocupado de la actualidad, incluso la relacionada con los eventos traumáticos como las guerras o el terrorismo, con lo cual la poca presencia, en los escenarios españoles, de la representación del conflicto árabe-israelí no puede justificarse con esta hipótesis, que queda por tanto naufragada.

6. Todas las obras citadas han sido representadas en España; queda por hacer una investigación sobre los textos que todavía no se han puesto en escena.

7. Para una información más detallada sobre el proyecto y el laboratorio, véase https://laembarcadaartivista.files.wordpress.com/2016/03/a4-teatro-del-oprimido-ii-cast_eusk.pdf 
Registramos que, en la esfera teatral, este evento bélico no ha causado las mismas reacciones que otras guerras han suscitado. Anotamos asimismo que la escena española no ha relacionado el terrorismo islamista con el terrorismo palestino; en el exhaustivo monográfico de la revista Signa dedicado al análisis de la dramatización del terrorismo en la escena española, Manuela Fox, editora del número, identifica esencialmente cuatro líneas argumentales: las obras que tratan el terrorismo de ETA, las relacionadas con el terrorismo de Estado, las originadas por los ataques del 11 de septiembre de 2001 y, por último, las creadas a raíz de las bombas en la estaciones del metro de Madrid el 11 de marzo de 2004 (Fox, 2011, 13-37)8. En tres de las cuatro líneas temáticas, se trata de eventos violentos y traumáticos relacionados directamente con la historia y la sociedad espańola; la cuarta categoría, la de la producción sobre el 11-S, se origina a partir de un evento histórico de interés global, cuyas consecuencias todavía perduran.

Los dramas basados en la violencia islamista no hacen referencia a las prácticas suicidas y homicidas de los extremistas palestinos, con lo cual se puede suponer que, desde la perspectiva de los creadores espańoles, no se establece una relación directa entre el terrorismo de corte religioso y las reivindicaciones violentas de la lucha palestina. Aunque en su monográfico

8. Según la definición propuesta por Manuela Fox, el terrorismo es "una «sucesión de actos de violencia ejecutados para infundir terror» [DRAE], pero lo que diferencia el terrorismo de la violencia, en general, es, sin duda, el aspecto político o, en caso de los fundamentalismos, el religioso. Los artífices de los actos terroristas quieren obtener provecho para su pueblo, o para su comunidad, por lo que no se trata, pues, de eventos gratuitos o que estén movidos por razones personales. Sin embargo, otra característica que convierte al terrorismo en un acto especialmente odioso es el hecho de que, a menudo, afecta directamente a la población civil” (2011, 14-15). 
"Pesan los muertos de ayer y de mañana". El conflicto Árabe-isRaelí en el teatro español actual

Fox trate el terrorismo de Estado solo en relación con España, la política de "asesinatos selectivos" llevadas a cabo por el gobierno de Israel podría entrar en esta casuística; sin embargo, no nos consta una producción dramática espańola que se haya enfrentado con el tema.

Es posible que la escasa atención que ha suscitado el drama del conflicto del Medio Oriente se justifique en la poca identificación con la causa que se tendría que representar, o sea que el motivo que tendría que mover la creación de un teatro comprometido a favor de una parte o de la otra de la contienda, entre los creadores españoles es difícil de encontrar. Mientras que ante un ataque de ISIS, la opinión pública occidental sabe tomar posición en contra de esta forma de violencia, cuando se trata de tomar partido en la cuestión palestina, las posiciones se fragmentan entre los sionistas, los antisionistas, los pacifistas, los xenófobos, etc.; y estas dudas se reflejan también a la hora de elegir este conflicto como argumento de una obra de teatro y de llevarlo a la escena. De acuerdo con lo afirmado por Itziar Pascual,

la noción de frontera, comprendida como hecho sociológico que adquiere forma espacial, es decisiva para aproximarse al universo palestino-israelí: un entramado casi infinito de fronteras que Warschawski sitúa entre israelíes y palestinos, por supuesto, pero también entre judíos e israelíes, religiosos y laicos, judíos europeos y judíos occidentales. Cabría citar muchas otras, siempre como sinónimo de tensión y conflicto: la frontera aquí implica una posición de en-frentamiento, estar en frente el uno del otro $(2009,70)$. 
Si se excluye la "trilogía del refugiado" de Magoa, las otras obras citadas se basan en la dialéctica de la violencia, es decir proponen un esquema dramático a dos, basado en el enfrentamiento entre grupos de dos personajes: de este conflicto estalla la acción. Reservado el derecho de admisión (1993), de Petra Martínez y Juan Margallo, es el resultado de la reescritura de tres obras: Adosados, de John Petrof; La mujer judia, de Bertolt Brecht, y El palestino, de Hassan Al Kadir. Los personajes son Él y Ella, una pareja de españoles que hacen comentarios xenófobos mientras leen las noticias en el periódico; con un cambio de escena, los dos asumen el papel de una pareja israelí, Ester y Amir, ella judía israelí, él también israelí, pero con sangre mixta, judía por parte de madre y musulmana por parte de padre. Amir es detenido injustamente por la policía israelí, que quiere que firme una falsa admisión de culpa; Ester querría que Amir aceptara la declaración por el bien de la familia, pero Amir se opone y acusa el gobierno israelí de una política persecutoria del Otro, no muy disímil de la nazi.

El suicidio del ángel (2007) de Aurora Mateos también presenta el conflicto a través del enfrentamiento entre una pareja, Ilán y Aicha, él judío israelí y ella musulmana marroquí. La acción se desarrolla en París durante los disturbios en las banlieues de la periferia urbana. Asimismo las tensiones se agravan entre los dos amantes: la esquizofrenia de Ilán estalla con fuerza y Aicha tiene que renunciar a su independencia económica y laboral para quedarse al lado de su compañero; además el equilibrio de la pareja está amenazado constantemente por las críticas de la madre de Ilán, una mujer israelí que nunca aparece en la escena, pero que se comunica con el hijo por teléfono e intenta romper la relación que Ilán tiene con una "enemiga” de 
“Pesan los muertos de ayer y de mañana”. El conflicto Árabe-israelí en el teatro español actual

Israel para que él tampoco termine en el lado equivocado del muro, es decir, entre los traidores. Ilán acabará asesinado por un policía francés que le confunde con un terrorista islamista: su paradójica muerte refleja el difundido pensamiento racista que acomuna la sociedad europea. En el drama aparece también otra pareja, un hombre y una mujer, que en realidad solo existe en la mente enferma de Ilán y representa el sentimiento de culpa que surge en el joven por no estar defendiendo Israel en la lucha contra los palestinos.

So happy together (2008) es un texto escrito por Jesús Laiz junto con Yolanda Pallín, José Ramón Fernández y Laila Ripoll. También en este tercer ejemplo sobre la representación del conflicto, los dramaturgos han construido el enfrentamiento a través de la oposición de dos parejas; Yasira y Abla son dos mujeres palestinas, Natán y Samuel, hermanos, son dos soldados israelíes. Los personajes constituyen un quiasmo. Yasira, voluntaria de la Media Luna Roja, decide inmolarse como una mártir de la lucha palestina después de asistir a la muerte de la hija que Abla lleva en el vientre, muerte acaecida porque Samuel, de guardia en un puesto de control, no ha dejado el paso a la ambulancia en la que las dos mujeres viajaban. Entre las víctimas heridas en el ataque terrorista de Yasira se halla también la hija de Natán, que logra sobrevivir gracias al pulmón del otro hijo de Abla, asesinado por el disparo de Natán que, mientras estaba patrullando, había confundido la pistola de juguete del niño por un arma verdadera. El drama termina con el arrepentimiento de Natán, que se declara objetor de conciencia (o sea pasa a ser un traidor para los israelíes) y se muda con la familia en una zona habitada por palestinos, donde su hija puede jugar libremente, a salvo de los episodios de intolerancia de los vecinos israelíes, que la rechazan por vivir gracias a un pulmón palestino. 
En So happy together se hace referencia a las persecuciones padecidas por los judíos a lo largo de la Historia, un argumento que sirve para que Samuel se justifique a sí mismo las violencias a las que se somete la población palestina (el Estado de Israel como un espacio seguro, donde los judíos puedan vivir sin miedo a nuevos pogromos y holocaustos; por esto hay que defenderlo de cualquier enemigo que pretenda negar su existencia); pero la referencia a las persecuciones sirve también para que Natán equipare la segregación palestina a la marginación judía en los guetos y en los campos de concentración nazis.

A pesar de que no se trate de una obra de un autor español, consideramos oportuno incluir, en esta rápida nómina de títulos relacionados con el conflicto de Oriente Medio, también el drama del argentino Mario Diament, Tierra del fuego (2013). La obra se estrenó en el Teatro Central de Sevilla (11-12/03/2016), dirigida por Claudio Tolcachir; luego se trasladó a Madrid, donde quedó en la cartelera del Teatro Español del 21/04/2016 al 12/06/2016, siempre bajo la dirección de Tolcachir?. El drama, como los anteriores, se basa en la contraposición entre un hombre y una mujer, ella de origen israelí y él palestino. El hombre, un terrorista, está detenido en prisión por el atentado en el que la mujer había resultado herida y su mejor

9. Al lado de la obra de Diament, cabe nombrar un texto inédito del autor argentino-israelí Jacobo Kaufmann, Se acabó la joda (2001). Se trata de un acto acusatorio contra la política argentina, ineficaz a la hora de integrar a los refugiados judíos que llegaron de la Europa fascista y, además, culpable de un silencio sordo delante de las amenazas antisemitas que se estaban cultivando en el país y que se concretaron, como se representa en el drama, en los ataques terroristas de 1994 a la Embajada de Israel y al edificio de la Asociación Mutual Israelita Argentina (en el que murieron 85 personas y 300 quedaron heridas). 
"Pesan los muertos de ayer y de mañana". El conflicto Árabe-israelí en el teatro español actual

amiga muerta. La mujer, a los 22 ańos del atentado, decide encontrarse con el terrorista para entender sus motivaciones, para comprender la perspectiva del enemigo. La finalidad es la apertura de un diálogo que lleve, algún día, a la comprensión mutua y a la paz.

Queda a un lado de esta escueta nómina de obras en español dedicadas al conflicto árabe-israelí el proyecto tripartito del madrileño Marco Magoa por tratarse de unos textos que tocan solo de manera marginal la cuestión palestina. El núcleo temático de la trilogía es el drama de los refugiados que escapan de situaciones de guerra, echándose en las aguas del mar Mediterráneo con la esperanza de una vida mejor. En el primer episodio, El cielo y yo (2015), el dramaturgo inserta en el texto algunos poemas del exiliado palestino Mahmud Darwish (1941-2008), autor además de la declaración de independencia del Estado de Palestina y considerado como uno de los mejores poetas árabes contemporáneos. La experiencia de este poeta le sirve a Magoa para presentar el drama del exilio y de las inicuas persecuciones a las que el pueblo palestino está sometido (Darwish fue encarcelado por los israelíes en repetidas ocasiones).

Al leer las conclusiones del estudio de Arie Vicente sobre la presencia judía en el teatro español contemporáneo, sus palabras suenan algo paradójicas, si las pensamos en relación con la producción dramática sobre el conflicto israelí-palestino; Vicente afirma lo siguiente:

En las obras de los autores contemporáneos aquí estudiadas, la lucha del judío o el converso constituye el proceso de victimización que, para estos autores, marca la larga historia de la humanidad. El converso, elemento estigmatizado de la sociedad, nos conduce a un proceso de reflexión de la 
historia. La importancia de este personaje reside en la expresión del antagonismo de dos mundos en un mismo ser. La tensión interna que se desprende de la acción dramática refleja la lucha entre dos componentes de lo español, por los que llegamos a la definición de España. Al mismo tiempo el marranismo nos revela el conflicto que existe en la asociación de lo judeo-cristiano y del hombre actual que busca su identidad (1991, 20).

En conclusión, uno de los errores más frecuentes cuando se habla de conflicto árabe-israelí es el de confundir lo judío y lo israelí; y sin embargo, las obras que hemos presentado brevemente aquí no rompen por completo este enlace erróneo puesto que en su casi totalidad se establece un paralelo entre persecuciones nazis y discriminación israelí, llegando en algunos casos a plantear una supuesta relación hereditaria entre el sistema persecutorio alemán y la agresividad de la política colonial de Israel.

A pesar de los intentos de recuperación de la memoria histórica relacionada con Sefarad, a nivel teatral España todavía no ha logrado llenar el vacío y sanar el trauma de las antiguas persecuciones; en la representación dramática, la víctima judía o conversa se sustituye por la víctima palestina, creando una ideal conexión entre los mártires de ayer y de hoy, con el cortocircuito psicológico de que los perseguidos del presente son víctimas de los hijos de los perseguidos del pasado: los israelíes como los hermanos Natán y Samuel de So happy together son a la vez los herederos de las víctimas de la Shoah y los nuevos carceleros de la enorme cárcel a cielo abierto que es el Estado de Israel, delimitado por el muro de Cisjordania y los puestos de control dispersados por todo el territorio. 
“Pesan los muertos de ayer y de mañana”. El conflicto Árabe-israelí en el teatro español actual

No obstante la buena cobertura mediática en la prensa española e internacional del conflicto entre palestinos e israelíes, hasta el momento la escena ibérica no ha proporcionado una producción muy amplia relacionada con esta cuestión, si la comparamos con otros eventos traumáticos como el 11-S y el 11-M o como el drama de los refugiados que escapan de las guerras actuales. En las ocasiones en las que los dramaturgos españoles se miden con este conflicto, intentan posicionarse siempre en el justo medio, en un equilibrio ético e ideológico que intenta representar la violencia, pero desde sus múltiples puntos de vista, reivindicando la paz y el diálogo como únicas vías para llegar a una resolución (utópica) de la situación conflictiva (baste pensar en las figuras de Natán y de Abla, en So happy together, en Ilán y Aicha, en El suicidio del ángel, y finalmente en la Yael de Tierra del fuego). La violencia palestina que se presenta en escena tiene su justificación en la agresión militar del Estado de Israel, de ahí que se motiven los atentados de Hasán, en Tierra del fuego, y de Yasira, en So happy together, como una respuesta desesperada a la situación de disparidad en la que se encuentra Palestina frente a Israel. En cambio, no nos constan obras filosionistas: si comparamos los personajes de Samuel y de Yasira, mientras que la voluntaria de la Media Luna Roja decide sacrificar su vida en un ataque bomba después de la violencia israelí sobre Abla, Samuel reivindica su derecho a defender con la fuerza a Israel porque es el único territorio donde los judíos pueden vivir sin miedo a nuevas persecuciones. En el personaje de Yasira se nota una evolución, aunque negativa; en cambio en el de Samuel no hay progresión, sino una inmutabilidad que no permite ningún tipo de diálogo o de confrontación positiva (al contrario que su hermano Natán). Y sin embargo, 
en estas obras no se quiere atribuir la culpa del conflicto a la población israelí en su totalidad. Como afirma Ilán en El suicidio del ángel, él, a pesar de ser israelí, nunca ha deseado la invasión de los territorios palestinos o la construcción de la barricada con Cisjordania; su esquizofrenia está causada también por el sentido de culpabilidad que siente frente a lo que sería su deber (es decir, defender, como los demás soldados israelíes, a su país) y su rechazo de la violencia (que hasta llega a concretarse en el amor por Aicha, que es musulmana, por tanto una enemiga).

La tendencia que se observa en el teatro espańol actual es la mayor atención que la escena ha reservado a la representación del drama de los refugiados y de las víctimas de los conflictos en el Oriente Próximo; en este sentido, la trilogía de Magoa se insertaría en el filón del teatro de denuncia de autores como Ignacio del Moral y Angélica Liddell, con títulos como $\mathrm{La}$ mirada del hombre oscuro (1993) e $Y$ los peces salieron a combatir contra los hombres (2004). El conflicto israelí-palestino es uno dentro de muchos, con lo cual esto también explica la poca presencia de este específico argumento en el teatro español actual.

Como ha escrito Aub en su diario, en este conflicto "pesan los muertos de ayer y de mańana"; el teatro puede ayudar en la comprensión de la complejidad de una situación en la que se han sumado, en ambos bandos y durante más de treinta años, diferentes experiencias traumáticas. La escena española que se ha interesado al tema ha logrado representar la dificultad de un enfrentamiento, que se puede definir dispar bajo muchos puntos de vista. A pesar de esto, la finalidad de este teatro llega sí a una mayor concienciación del espectador occidental, pero sin un real planteamiento para la resolución 
"Pesan los muertos de ayer y de mañana". El conflicto árabe-israelí en el teatro español actual

del conflicto. Más eficaces y viables nos parecen ser las propuestas como la del taller del grupo israelí-palestino Combatants for Peace, que ofrecen una colaboración concreta entre los miembros de los dos bandos, involucrando además los participantes ajenos al enfrentamiento en un proceso de cambio a través de las técnicas y los lenguajes teatrales.

\section{REFERENCIAS BIBLIOGRÁFICAS}

Alberola, Miquel. "El Rey, a los sefardíes: «¡Cuánto os hemos echado de menos!»”. En: El Pais. Madrid, 30/11/2015.

Aub, Max. Diarios (1939-1972). Edición de Manuel Aznar Soler. Barcelona: Alba Editorial, 1998.

. Nuevos diarios inéditos (1939-1972). Edición de Manuel Aznar Soler. Sevilla: Renacimiento, 2003.

. Imposible Sinaí. Edición de Eleonor Londero. Segorbe: Fundación Max Aub, 2002.

Baer, Alejandro. "Los vacíos de Sefarad. La memoria del Holocausto en España”. Politica y Sociedad, 48.3, 2011, 501-518.

Barrenetxea Marañón, Igor. "Sufrir y humanizar. El conflicto palestino-israelí en el cine de ficción”. Filmhistoria, 24.2, 2014, 1-21.

Bermejo Laguna, José Manuel. "Ideologías en conflicto en el siglo XXI: islamofobia vs occidentalofobia”. Revista de Paz y Conflictos, 9.1, 2016, 133-156.

Córdoba Hernández, Ana María. "El conflicto palestino-israelí visto desde España: oscilaciones y tendencias de la opinión pública”. Ámbitos, 20, 2011, 149-174. . "España, Israel y Palestina: pasado y presente de sus relaciones diplomáticas". Historia y Politica, 26, 2011, 291-323.

Diament, Mario. Tierra del fuego. Buenos Aires: Continente, 2013. 
Di Pastena, Enrico. "Estudio introductorio". En: Mayorga, Juan. Teatro sulla Shoah. Himmelweg, Il cartografo, JK. Pisa: ETS, 2014, 5-62.

Fox, Manuela. "Teatro español y dramatización del terrorismo: estado de la cuestión”. Signa, 20, 2011, 13-37.

Londero, Eleonor. "Estudio introductorio". En: Aub, Max. Imposible Sinai. Segorbe: Fundación Max Aub, 2002, 11-44.

Maciá-Barber, Carlos. "Ética, fotoperiodismo e infancia: imagen del conflicto palestino-israelí en España”. Cuadernos.Info, 33, 2013, 89-98.

Martínez, Petra; Margallo, Juan. Reservado el derecho de admisión. Madrid: Sociedad General de Autores de España, 1993.

Mateos, Aurora. El suicidio del ángel. Granada: Diputación de Granada, 2008.

Monti, Silvia. Sala d'attesa. Il teatro incompiuto di Max Aub. Roma: Bulzoni, 1992.

Pascual, Itziar. "De la frontera a la encrucijada". Acotaciones, 23, 2009, 69-81.

Vicente, Arie. Lo judío en el teatro español contemporáneo. Madrid: Editorial Pliegos, 1991. 